\title{
Water Governance Decentralisation and River Basin Management Reforms in Hierarchical Systems: Do They Work for Water Treatment Policy in Mexico's Tlaxcala Atoyac Sub-Basin?
}

\author{
Cesar Casiano Flores *, Vera Vikolainen ${ }^{\dagger}$ and Hans Bressers ${ }^{\dagger}$ \\ Department of Governance and Technology for Sustainability (CSTM), University of Twente, Enschede 7500AE, \\ The Netherlands; v.vikolainen@utwente.nl (V.V.); j.t.a.bressers@utwente.nl (H.B.) \\ * Correspondence: c.a.casianoflores@utwente.nl; Tel.: +31-68-174-6250 \\ † These authors contributed equally to this work.
}

Academic Editors: Sharon B. Megdal, Susanna Eden and Eylon Shamir

Received: 22 February 2016; Accepted: 11 May 2016; Published: 19 May 2016

\begin{abstract}
In the last decades, policy reforms, new instruments development, and economic resources investment have taken place in water sanitation in Mexico; however, the intended goals have not been accomplished. The percentage of treated wastewater as intended in the last two federal water plans has not been achieved. The creation of River Basin Commissions and the decentralisation process have also faced challenges. In the case of Tlaxcala, the River Basin Commission exists only on paper and the municipalities do not have the resources to fulfil the water treatment responsibilities transferred to them. This lack of results poses the question whether the context was sufficiently considered when the reforms were enacted. In this research, we will study the Tlaxcala Atoyac sub-basin, where water treatment policy reforms have taken place recently with a more context sensitive approach. We will apply the Governance Assessment Tool in order to find out whether the last reforms are indeed apt for the context. The Governance Assessment Tool includes four qualities, namely extent, coherence, flexibility, and intensity. The assessment allows deeper understanding of the governance context. Data collection involved semi-structured in-depth interviews with stakeholders. The research concludes that the observed combination of qualities creates a governance context that partially supports the implementation of the policy. This has helped to increase the percentage of wastewater treated, but the water quality goals set by the River Classification have not been achieved. With the last reforms, in this hierarchical context, decreasing the participation of municipal government levels has been shown to be instrumental for improving water treatment plants implementation policy, although many challenges remain to be addressed.
\end{abstract}

Keywords: Mexico; water governance; governance assessment; sanitation; water treatment plants policy; Tlaxcala sub-basin

\section{Introduction}

During the last decades of policy reforms, new instruments have been developed and substantial economic resources have been invested to improve water sanitation quality in Mexico. An important apparatus of institutions at river basin level has been established, such as river basin organisations, river basin councils and auxiliary bodies. "Since 1992, in addition to the 13 river basin organisations implementing the National Commission of Water (CONAGUA) policies in each hydrographic region, 26 river basin councils have been created as consultative bodies, working closely with 32 river basin commissions [ ... ]" [1] (p. 107). However, the creation of River Basin Organisations has been described as a mere offices' decentralisation instead of a decentralisation of the policy. The case of Tlaxcala 
exemplifies this national situation. "Decision-making power is still centralised within the hands of CONAGUA and its regional/local offices" [1] (p. 17).

Despite the governmental efforts, pollution levels have increased in different parts of the country and only a few studies have addressed this [2]. Water pollution contributes to ecological damage and health issues of the population with economical consequences [3]. "Over half of the world's hospital beds are occupied with people suffering from illnesses linked with contaminated water and more people die as a result of polluted water than are killed by all forms of violence including wars" [4]. In this paper, we focus on Tlaxcala's Alto Atoyac sub-basin, where almost $80 \%$ of the state population lives and whose main river Zahuapan, a tributary of the Atoyac River, is considered the third most polluted in Mexico. The Alto Atoyac sub-basin has called national attention as well as media coverage, since the river pollution affects more than two million people in the states of Tlaxcala and Puebla [5], The NGO Fray Julian Garces from Tlaxcala, produced a documentary about the health impacts on the population that lives close to the river, and the media have also reported cases of leukaemia and respiratory diseases [6].

In order to solve water issues, the Mexican government has promoted a more integrated water management at the basin level. In the case of Tlaxcala, the federal government created the Atoyac-Zahuapan River Basin Commission on 26 November 2009. The Commission was expected to facilitate the implementation of river basin councils' strategy; inter-governmental co-ordination; and social participation at the sub-basin level [1] (p. 111). However, in the following six years the Commission never had a session and most of the state and municipal actors as well as NGOs were unaware of its existence. Governmental actors commonly perceive that stakeholders' participation increases complexity without positive results. The inoperability of the Atoyac-Zahuapan River Basin Commission shows that following the worldwide trend towards decentralisation in water management could not produce the expected results in a centralised policy making context. Water policy is still implemented through the national programs of CONAGUA. Hence it is necessary to consider the importance of the context and investigate whether the reform was apt for the situation, because central government could still play an important role [7] (p. 22).

Governance as a normative concept has been highly promoted by international organisations as an answer to solve water problems. Contextual factors are also mentioned as an important element to consider when policies are created and implemented. Although literature provides examples of how context matters, it generally presents "water governance" as the recipe for all water management problems. In this study, we give a more contextual answer and demonstrate the importance of context in a systematic manner. The central question we ask in this article is: how apt have the water treatment policy reforms been for the governance context in Tlaxcala's Alto Atoyac sub-basin? We assess the governance context of the Water Treatment Plant (WTP) policy in Tlaxcala, including planning, construction, operation, and monitoring. The assessment is conducted using the Governance Assessment Tool (GAT), which includes descriptive-analytical and semi-normative elements.

\section{Theoretical Framework and Methodology}

As Ostrom explains "[t]here is no panacea where a single type of governance system applies to all environmental problems" [8] (p. 15176). In this sense, one of the main concerns from the academic perspective is to propose frameworks that consider contextual factors [8-15]. "[W]e observe a gradual shift from the promotion of simplistic panaceas for water governance reform towards more context-sensitive approaches" [12] (p. 11), as well as the necessity of developing frameworks and methods that allow comparison across cases [10,12,16-19]. In addition to this, "[t]he field of water governance lacks both a systematic empirical base and a theoretical understanding of governance system" [12] (p. 20). Furthermore, "there is a lack of attention to implementation of agreements or regulations from a governance perspective" [15] (p. 736), while "methods to deal with the complexity of governance systems are missing in general" [12] (p. 17). The Tlaxcala case presented here contributes in different degrees to these academic concerns from an institutional perspective. We believe that our 
framework and method can clarify the complexity when analysing water governance implementation. The methodology used in our study is called the Governance Assessment Tool (GAT).

The GAT defines governance as:

"the combination of the relevant multiplicity of responsibilities and resources, instrumental strategies, goals, actor-networks and scales that forms a context that, to some degree, restricts and, to some degree, enables actions and interactions" [20] (p. 6).

The GAT is based on Contextual Interaction Theory (CIT) [21-24]. CIT focuses on the context in which people work as being pivotal to the outcome of their interactions and divides this context into descriptive-analytical and semi-normative categories. By semi-normative we imply that the normative content of these qualities is derived from and thus dependent on the importance and urgency of the implementation of policies and projects under assessment. The GAT analyses what governance conditions are especially supportive or restrictive for the effective realisation of such interventions.

The assessment of these categories allows deeper understanding of the governance context and how it impacts the policy implementation. The categories are separated in two sets: the five dimensions (multi-level, multi-actor, multi-faceted, multi-instrument and multi-resource based) and the four semi-normative qualities (coherence, extent, flexibility, and intensity) that are employed to analyse the governance interactions [14]. The GAT is made up of a 'matrix' model consisting of these five dimensions and four qualities [25]. See Table 1 below.

Table 1. Water governance matrix.

\begin{tabular}{|c|c|c|c|c|}
\hline $\begin{array}{l}\text { Governance } \\
\text { Dimension }\end{array}$ & Extent & Coherence & Flexibility & Intensity \\
\hline Levels \& Scales & $\begin{array}{l}\text { How many levels } \\
\text { are involved and } \\
\text { dealing with an } \\
\text { issue? Are there } \\
\text { any important gaps } \\
\text { or missing levels? }\end{array}$ & $\begin{array}{l}\text { Do these levels work } \\
\text { together and do they trust } \\
\text { each other between levels? } \\
\text { To what degree is the mutual } \\
\text { dependence recognised? }\end{array}$ & $\begin{array}{l}\text { Is it possible to move up } \\
\text { and down levels } \\
\text { (upscaling and } \\
\text { downscaling) given the } \\
\text { issue at stake? }\end{array}$ & $\begin{array}{l}\text { Is there a strong } \\
\text { impact from a certain } \\
\text { level towards } \\
\text { behavioural change } \\
\text { or management } \\
\text { reform? }\end{array}$ \\
\hline $\begin{array}{l}\text { Actors \& } \\
\text { Networks }\end{array}$ & $\begin{array}{l}\text { Are all relevant } \\
\text { stakeholders } \\
\text { involved? Who } \\
\text { are excluded? }\end{array}$ & $\begin{array}{l}\text { What is the strength of } \\
\text { interactions between } \\
\text { stakeholders? In what way } \\
\text { are these interactions } \\
\text { institutionalised in stable } \\
\text { structures? Do the } \\
\text { stakeholders have } \\
\text { experience in working } \\
\text { together? Do they trust and } \\
\text { respect each other? }\end{array}$ & $\begin{array}{l}\text { Is it possible that new } \\
\text { actors are included or } \\
\text { even that lead shifts } \\
\text { from one actor to } \\
\text { another when there are } \\
\text { pragmatic reasons for } \\
\text { this? Do the actors share } \\
\text { in social capital allowing } \\
\text { them to support each } \\
\text { other's tasks? }\end{array}$ & $\begin{array}{l}\text { Is there a strong } \\
\text { impact from an actor } \\
\text { or actor coalition } \\
\text { towards behavioural } \\
\text { change or } \\
\text { management reform? }\end{array}$ \\
\hline $\begin{array}{l}\text { Problem } \\
\text { Perspectives \& } \\
\text { Goal Ambitions }\end{array}$ & $\begin{array}{l}\text { To what extent } \\
\text { are the } \\
\text { various problem } \\
\text { perspectives taken } \\
\text { into account? }\end{array}$ & $\begin{array}{l}\text { To what extent do the } \\
\text { various goals support each } \\
\text { other, or are they in } \\
\text { competition or conflict? }\end{array}$ & $\begin{array}{l}\text { Are there opportunities } \\
\text { to re-assess goals? }\end{array}$ & $\begin{array}{l}\text { How different are the } \\
\text { goal ambitions from } \\
\text { the status quo? }\end{array}$ \\
\hline $\begin{array}{l}\text { Strategies \& } \\
\text { Instruments }\end{array}$ & $\begin{array}{l}\text { What types of } \\
\text { instruments are } \\
\text { included in the } \\
\text { policy strategy and } \\
\text { are implemented; } \\
\text { and which } \\
\text { are excluded? }\end{array}$ & $\begin{array}{l}\text { To what extent is the } \\
\text { resulting incentive system } \\
\text { based on synergy? Are there } \\
\text { any overlaps or conflicts of } \\
\text { incentives created by the } \\
\text { included policy } \\
\text { instruments? }\end{array}$ & $\begin{array}{l}\text { Are there opportunities } \\
\text { to combine or make use } \\
\text { of different types of } \\
\text { instruments? Is there } \\
\text { a choice? }\end{array}$ & $\begin{array}{l}\text { What is the implied } \\
\text { behavioural } \\
\text { deviation from } \\
\text { current practice and } \\
\text { how strongly do the } \\
\text { instruments require } \\
\text { and enforce this? }\end{array}$ \\
\hline
\end{tabular}


By analysing the five dimensions of governance according to the four qualities of the governance regime, one can attain a very pragmatic understanding of how different elements of governance interact and hence influence a particular implementation setting. Extent refers to the completeness of the regime in terms of relevant aspects, such as actors or instruments. Coherence relates to how the various elements of the regime strengthen or weaken each other. Flexibility refers to the existence of different roads according to the opportunities or threats that arise during the implementation. And finally, intensity is "the degree to which the regime elements urge changes in the status quo or in current developments" [23] (p. 93).

As demonstrated in previous research, the GAT framework can be applied when there is a multi-level setting with interdependency among the actors. This means that different levels should act as semi-autonomous units and power must be diversified [26]. This interdependence must at least be classified as a "legislatively initiated coordination" [26] even if it is not fully implemented. The GAT has shown important strengths in the analysis of water projects implementation in the Netherlands [23], Canada [24], in North Western Europe [27], Romania [28], and Mexico [29]. The methodology has proven to be useful for comparison across governance structures. This is important, since this study is part of a broader comparative project regarding different institutional arrangements at the sub-basin level. The Governance Assessment Tool (GAT) applied in this research is related to the UN's (United Nations) fifth methodology [30] and it is part of the 25 assessment tools compiled by OECD (Organisation for Economic Co-operation and Development) [31] (p. 31).

Data collection consisted of 21 semi-structured in-depth interviews that took place between May 2014 and July 2015. The questions in Table 1 were used as an interview guideline. The interviewees included representatives of three government levels, the private sector and non-governmental organisations. In most of the organisations, the directors and heads of the departments were interviewed. Table 2 shows the affiliations of the interviewed actors.

Table 2. Actors interviewed per stakeholder category in the Tlaxcala Alto Atoyac sub-basin.

\begin{tabular}{|c|c|c|c|c|}
\hline Water Utility (WU) & State Level & Federal Level & Industry Sector & $\begin{array}{l}\text { Organisations of } \\
\text { Civil Society }\end{array}$ \\
\hline $\begin{array}{c}\text { CAEM Tlaxcala } \\
\text { (WU of Tlaxcala municipality) }\end{array}$ & $\begin{array}{c}\text { Coordinacion General de } \\
\text { Ecologia }\end{array}$ & $\begin{array}{l}\text { CONAGUA Balsas } \\
\text { Organization }\end{array}$ & Textile Industry & Colegio de Tlaxcala \\
\hline $\begin{array}{l}\text { CAEM Chiautempan } \\
\text { (WU of Chiautempan } \\
\text { municipality) }\end{array}$ & $\begin{array}{c}\text { SECODUVIT } \\
\text { (Ministry of Infrastructure) }\end{array}$ & $\begin{array}{l}\text { CONAGUA } \\
\text { Delegation in } \\
\text { Tlaxcala }\end{array}$ & & $\begin{array}{l}\text { Fray Julian Garcés } \\
\text { NGO }\end{array}$ \\
\hline $\begin{array}{c}\text { CAEM Huamantla } \\
\text { (WU of Huamantla municipality) }\end{array}$ & $\begin{array}{c}\text { CSITARET } \\
\text { (Centre for Integral Water } \\
\text { Treatment) }\end{array}$ & & & $\begin{array}{l}\text { PRONATURA } \\
\text { NGO }\end{array}$ \\
\hline $\begin{array}{c}\text { CAEM Apizaco } \\
\text { (WU of Apizaco municipality) }\end{array}$ & $\begin{array}{c}\text { CEAT } \\
\text { (State Water Commission) }\end{array}$ & & & \\
\hline $\begin{array}{c}\text { CAEM Tlaxco } \\
\text { (WU of Tlaxco municipality) }\end{array}$ & & & & \\
\hline
\end{tabular}

The document for the creation of the Atoyac-Zahuapan Commission was the starting point to select the actors to be interviewed at the sub-basin level. The fact that the last federal administration focused its water sanitation policy on building Water Treatment Plants (WTPs) in the municipalities of San Pablo del Monte, Chiautempan, Huamantla, Contla de Juan Cuamatzi, and the optimisation of Tlaxcala, Tlaxco, Apizaco and Ixtacuixtla de Mariano Matamoros WTPs [32] (p. 99) was also considered in sampling the interviewees.

The quality of the water governance regime is assessed inductively based on the interviewees' answers. To support this primary research, official international and national documents, and electronic newspapers were also reviewed. Each response was first assessed individually and then compared with the rest of the actors in order to reach an assessment per cell. The result was then contrasted with the other four categories. When the quality was ranked as moderate or high in most of the categories, the quality was graded as supportive. Otherwise it was ranked as restrictive. 


\section{Location of the Study}

The Alto Atoyac sub-basin covers 69 municipalities in the states of Puebla and Tlaxcala. Its main rivers are the Zahuapan, Atoyac, and Alseseca. The sub-basin belongs to the Balsas River Basin formed by 12 sub-basins in eight states [32]. The state of Tlaxcala has a population of 1,169,936 inhabitants according to the last census in 2010. It is the smallest federal entity in size just after Mexico city. It represents $0.2 \%$ of the Mexican territory and generates $0.56 \%$ of the National Gross Domestic Product [33]. The municipalities with the largest populations are Tlaxcala $(89,795)$, Huamantla $(84,979)$, and Apizaco $(76,492)$ [34]. The municipalities of Apizaco, Tlaxcala, and Chignahuapan alone concentrate $30 \%$ of the economic activities, $35 \%$ of employees, and $54 \%$ of the economic production of the state [33]. The main economic activities of the population are: $53 \%$ services, $32 \%$ industry, and $15 \%$ agriculture. The manufacturing industry employs $34 \%$ of the workforce [33]. The part of the Atoyac-Zahuapan sub-basin that belongs to Tlaxcala hosts $79.5 \%$ of the state inhabitants [35] (p. 20). Among the most important municipalities are the Tlaxcala municipality, Villa Vicente Guerrero, Apizaco, and Chiautempan [35] (p. 18). The sub-basin covers a territory of $1485 \mathrm{~km}^{2}$ [36]. The Zahuapan River is the most important and crosses 25 of the 60 municipalities that comprise the state, while other 20 municipalities discharge into it indirectly [37] (pp. 18-19). Figure 1 shows the location of the study.

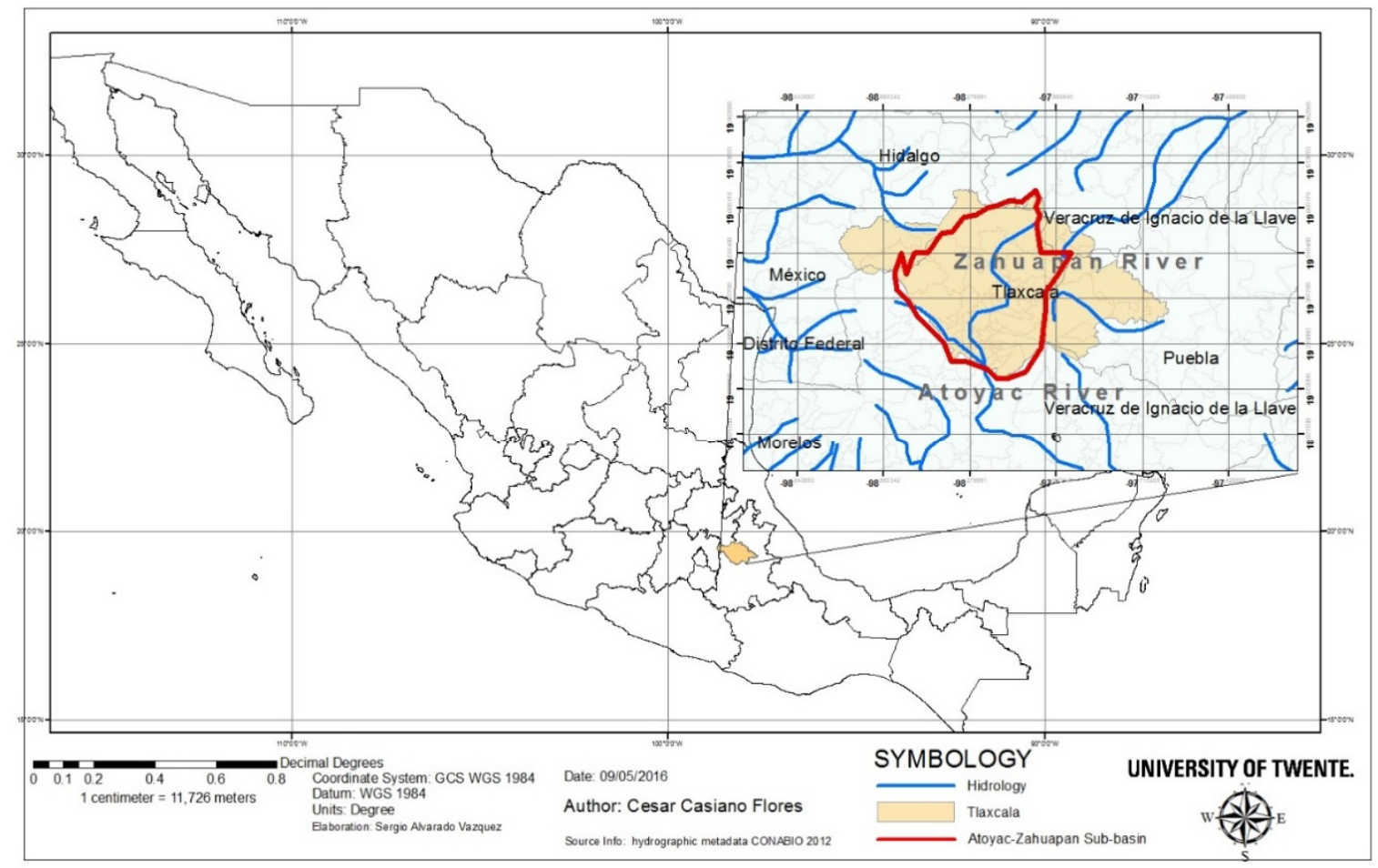

Figure 1. Location of the Atoyac-Zahuapan sub-basin in the state of Tlaxcala. Source: Authors' elaboration.

\section{Background of the Tlaxcala Case Study}

The federal government is the actor with the most decision-making power in the Mexican water sanitation policy and the institution in charge is CONAGUA. The CONAGUA is organised in three levels: Central Headquarters, Basin Organisations and Local Delegations [38] (p. 12). Between 1999 and 2010 the budget from the federal government for water programs increased from 17.64 to 360.2 USD millions [39] (p. 6). In 2016 the CONAGUA budget is more than 2000 USD millions for direct investments [40] and the water sanitation capacity in the country in 2015 was estimated to be $55 \%$ [41]. 
Although the federal government transferred its responsibilities to lower governmental levels decades ago, CONAGUA remains the main water management actor. The delegation of water related services to the municipal level started in the 1980s [42] (p. 33). In 1983, the reform established water related services as an exclusive function of the municipalities and the state government as transitional entities. In most of the cases the state government transferred the new obligation to the municipalities immediately [43] (p. 84). However, the 115 Article of the Mexican Constitution also mentioned that municipalities could coordinate and associate their efforts with other municipalities or the state level to provide the water services [44] (p. 17). The policy of delegating water related services to water utilities (WUs) at the municipal level has been criticised during the last years. The municipal government has two characteristics: it is the closest to the population, but has a short-term government of three years [42] (p. 37).

In the state of Tlaxcala the interest in water sanitation started in 1985 with the creation of [35] (p. 16):

- $\quad$ The Company for Control of Polluted Water in the State of Tlaxcala (ECCAET)

- The State Drinking Water and Sewage Commission (CAPAET)

In 1994, the Coordination of Ecology (CGE) office took over the functions from the ECCAET, and the CAPAET's responsibilities were conferred to the municipalities [35] (p. 16). In 2009, the State Water Law created two organisations whose operations started in 2011 with the newly elected government:

- The State Water Commission (CEAT): the maximum organisation for water related matters with technical, normative and consultation capacity;

- The Centre for Integral Water Treatment (CSITARET), in charge of the water sanitation policy, with the operation and the monitoring of water discharges quality of some WTPs' among its functions.

The sanitation of the Alto Atoyac basin has been among the main projects since the last federal government 2006-2012 [45] (p. 64). Between 2007 and 2011, CONAGUA with the support of the state and municipal level conducted an important number of studies and WTPs were built as well as collectors. In the last decade, NGOs and the media from the states of Puebla and Tlaxcala pressured the government by stating the high levels of pollution and its impacts. Also the green political party in the national Congress and the Senate pointed out this situation [46]. The results of the Alto Atoyac basin sanitation have been mixed. The state of Tlaxcala reports more improvements than the state of Puebla. The last study found that the main polluters in the Alto Atoyac sub-basin are the textile industry, slaughterhouses, the food and construction industries, and the municipal discharges [47]. Only 400 out of 3675 industries have water discharge permits [48], and the pollution levels are eight times higher than the national norm [49].

In the state of Tlaxcala, the amount of discharges treated between 2010 and 2013 remained around 40\%-43\%. In September 2014, the CSITARET implemented a program to increase water treatment capacity by rehabilitating 15 WTPs. These plants do not require energy to work. The state expects to treat $63 \%$ of water discharges with this investment [50]. However, industrial discharges are seen as one of the most important problems. The industrial park Quetzalcoatl has been highly criticised and linked to health problems by different NGOs.

In 2011, only two out of 128 water treatment plants were operating and in May 2014, the state government announced that 61 WTPs were working, representing $61.08 \%$ of the water treatment capacity. The state government directly operates nine plants, which are located in the municipalities of Apetatitlan, Apizaco, Tetla de la Solidaridad, Huamantla, Tlaxco, Ixtacuixtla, Tepeyanco, and Tlaxcala. This is shown in Figure 2 below. 


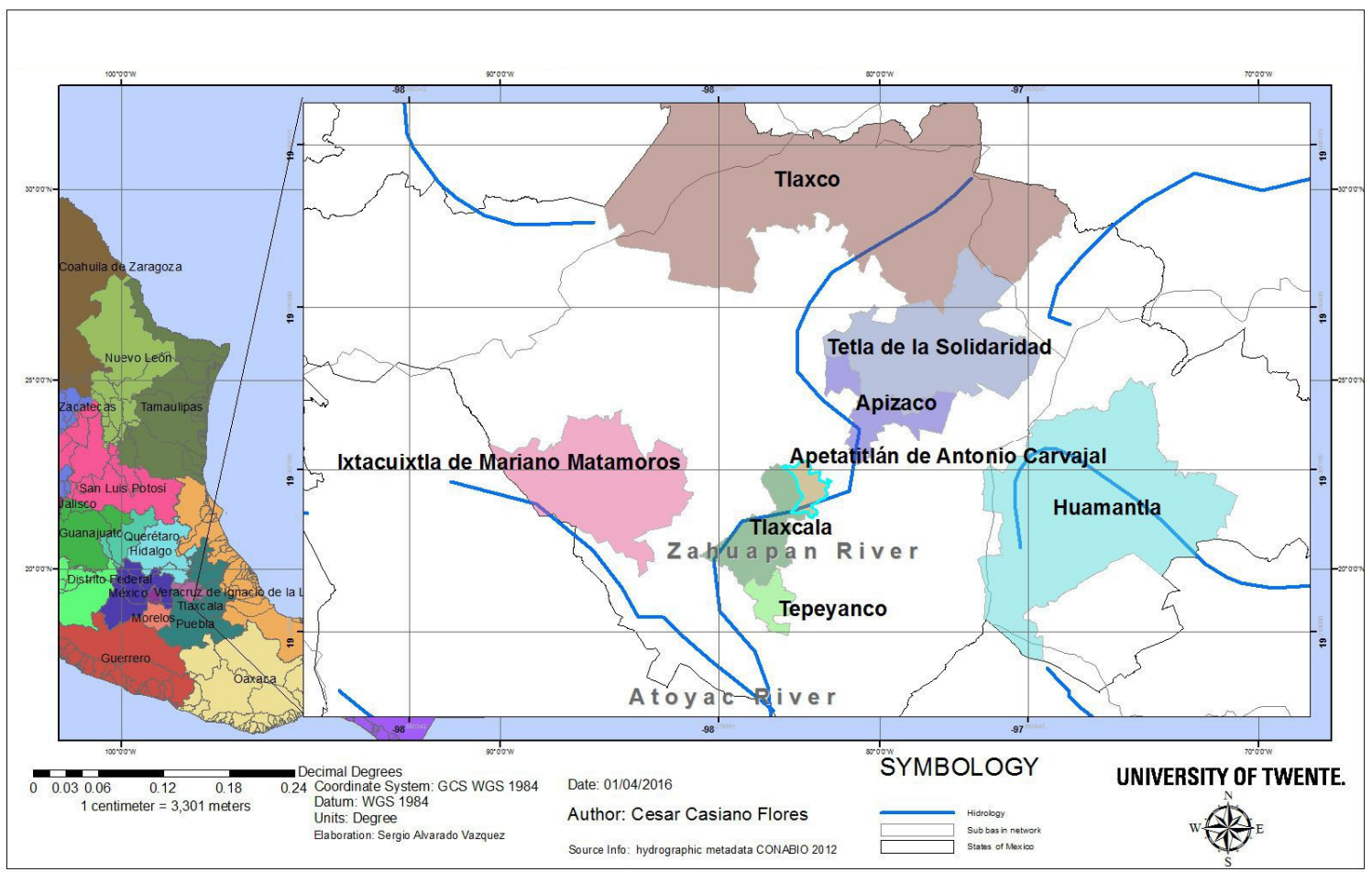

Figure 2. Location of the municipalities where WTPs are operated by the state level. Source: Authors' elaboration.

Three main legal reforms also took place during this period: the River Classification (2012), the sanctions to water polluters in the State Penal Code (2013), and changes to the Federal Fund for Strengthening the Municipalities (2014). River Classification is very important, because it is the legal instrument that sets water quality discharge limits, goals and stages for the basin [51].

Along with the governmental efforts mentioned, civil society has been demanding an improvement in the water treatment quality. One of the most important situations occurred in 2006, when NGOs sued the government for health damages caused by the Atoyac River pollution in the Tribunal Latinoamericano del Agua. The tribunal exhorted the governments from Tlaxcala and Puebla to solve the pollution problem [52]. During that year, the state government signed an agreement with the Instituto Politécnico Nacional (IPN) to diagnose the situation. However, the study did not include industrial discharges nor heavy metal discharges from the municipal water utilities and was not open to the citizens. This brought another legal process from the NGOs to ask for transparency. The NGO Centro Fray Julián Garcés Derechos Humanos y Desarrollo Local A.C has continued very actively in its demands for improvement of the water quality. In the light of its wide coverage in the national media in 2014, communities in the Atoyac-Zahuapan sub-basin required the intervention of the Congress for health issues. The Congress demanded the intervention of the Ministry of the Environment and Natural Resources, CONAGUA and the Attorney General's Office for Environmental Protection to monitor that wastewater discharges met the norm in the sub-basin. Some months later, CONAGUA answered this demand by providing information about the actions they took to monitor wastewater discharges in the last year as well as the actions they were developing.

\section{Governance Assessment of the Context}

The governance assessment results are presented in the following sub-sections. 


\subsection{Levels E Scales-The Three Governmental Levels Are Involved; However, the Federal and State Government Are the Main Drivers of the Policy}

While three levels of government (municipal, state, and federal) are involved in water sanitation policy, the state and federal play the main role. Their relation is institutionalised by the Rules of Operation for Water Programs from CONAGUA and the regionalisation policy executed by the state government. The first aspect, the Rules of Operation are applied in the Wastewater Treatment Program (PROTAR) launched in 2009, the Urban Potable Water and Sewerage Program (APAZU) from 1990 and the Rural Waterworks Development Program (PROSSAPYS) from 1996. The Rules include the creation of the Commission of Regulation and Follow up (CORESE). This Commission is established between the federal government through CONAGUA and the state government, excluding the municipal level. The two actors have monthly meetings, where the state level can present proposals to CONAGUA about programs and actions. The second aspect is the regionalisation policy for water sanitation. The Tlaxcala Water Law allows this process through agreements between the state government and the WUs at the municipal level. Currently the state government is in charge of nine WTPs. The state and federal government are studying the possibility of strengthening this policy. Most of the WUs agree with the policy.

The state and the federal government collaborate in the planning and the construction of federal projects, while the operation is the responsibility of the municipal level. The state government has also developed its own sanitation programs in collaboration with the WU at the municipal level. One example is the construction of the WTP for the slaughterhouse in the municipality of Apizaco between 2012 and 2013, its operation being the responsibility of the WU.

There is a certain trust among the levels, but lack of trust is perceived within each level. For example at the municipal level there is a lack of information sharing between the infrastructure department and the WU. The Basin Council and CONAGUA's Delegation are not working as close as in 2013 due to political changes after elections and because the Council mentioned that other sub-basins had priority. However, the Council experiences commitment from the state government. The mutual dependence is recognised by the three governmental levels since each one has specific responsibilities and resources. For example there is a necessity to co-invest, to build and operate the required infrastructure for the sanitation of the sub-basin. On many occasions the WU mentioned the importance of the federal government resources.

There is no possibility to move responsibilities up and down levels in a pragmatic manner given the issue at stake. The state and federal law as well as the Rules of Operation are clear about the role of each level. The order is respected from top to down: federal, state, and municipal. However, the agreements signed between the municipal and the state level, have permitted to consolidate the state level as the implementer of the water sanitation policy.

The strongest impulse towards behavioural change comes from the federal level followed by the state level. CONAGUA has the most important budget and main programs; it is also the actor that participates the most and prepares the national water legislation. The actors interviewed experience that the state and federal level work to strengthen the sanitation and regionalisation policy and to rehabilitate different plants already constructed.

\subsection{Actors \& Networks - The Network to Implement the Policy Is Composed of Governmental Actors Who Do Not Allow the Participation of Social Actors}

Not all the interviewed stakeholders are included in the policy implementation. Exclusion of the municipality is common in planning and construction. The social actors that are mentioned in the document establishing the Zahuapan Commission do not participate actively in the water policy. Some very active organisations, such as NGO Fray Julian Garces, were even excluded. The industry sector as well as civil society is not involved in the WTP policy. NGOs are not commonly taken into consideration, neither is academia and when they are, it is because the political actors feel comfortable with that specific group. One state actor said, "society is merely political groups who complicate the 
decision-making process". From the government perspective, society is not interested and the industry is limited to meeting the requirements. Civil society participates by pushing the government.

The main strength of interaction is found in the CONAGUA's programs, they are institutionalised through the Rules of Operation, the most important action being the CORESE monthly meetings between the federal and state government. The state government has seen benefits from the CORESE: they have made proposals there, which have received positive answers from the federal government. The Zahuapan River Basin Commission should be the auxiliary organisation where different stakeholders meet and make proposals for basin sanitation policy. However, the Commission has never had any session.

As in other parts of the country, government elections affect continuity of the policies, their implementation and the trust in the network. Many interviewees at the federal level mention the lack of interest from the municipal government to operate the plants. Nationally, "[m]unicipalities change government every three years, and water service providers change General Directors every 18 months on average" [1] (p. 29). The federal government has been more stable, many of the directors and heads of the departments have continued after the 2012 election at the federal government. But the high profile actors such as the federal delegate and the Balsas Basin director were changed. There is no tradition of different stakeholders working together. Since the policy of regionalisation, cooperation between the federal and state level has improved and they have been working closer.

The relation between the federal and the state government with the NGOs is generally characterised by a lack of trust. Besides the legal demand in 2006, in 2008 the NGO Fray Julian Garces started a legal process to oblige the government to publish the 2008 results about water pollution in Tlaxcala. After many allegations the government accepted this, but the results were highly criticised since they were general and did not include the industrial sector. The NGO has also produced a documentary about the health impacts of the river pollution. There is a higher degree of trust from the government to the industry, but the feeling is not mutual. One of the state level actors said "we have been explaining the situation to the industry sector and their response has been positive". The industry sector, on the other hand, distrusts the government mainly for their discretional law implementation and lack of support for the industry.

The policy process takes place only among government actors, without including new actors. It is not a common practice that leadership shifts from one actor to another. The main impact seems to come from the coalition of the state and federal government. The social capital sharing is limited to the governmental actors. The impulse towards change comes from two actors, the government and the NGOs, but there is no coalition among them. The NGO has only managed to set the importance of water sanitation on the agenda.

\subsection{Problem Perspectives and Goal Ambitions-The Main Perspectives Considered for the Policy Implementation Are Those of the Federal and State Government, and the Achievements Are Far from the Goals Set}

The main perspectives considered are of the federal and state level. Participation from industry, society and the municipal level is not really promoted and their perspectives are not considered. This has had implications in the past with the failure of WTPs' construction, when for example the state and federal government built a plant for a municipality with Israeli technology and the municipality did not have the resources to operate it. The building of the water treatment plants has just started, considering the lack of resources from the municipalities to operate them. The problem perspectives of NGOs are not considered by the government.

The system was created to support the governments' goals. For example, one of the WUs did not have debts with CONAGUA and this helped them to invest in the municipality via payback from CONAGUA. However, most of the WUs have debts with CONAGUA due to lack of payments for water extraction and wastewater discharges; therefore, they cannot access these benefits. 
There is a competition between the goals of economy and the environment. On some occasions the government does not enforce the law because industry threatens to close factories, provoking unemployment. One of the government actors said that some industries have been permitted to operate without water treatment for 10 years. The NGOs comment that the Mexican government has been easy with companies in order to promote jobs. Except for the operation of some WUs, the perspective and goal ambitions of the state and federation are more aligned than before. Both have a similar time perspective and a more balanced relation. As for the industry sector, each actor has its own perspective due to its particular interest and vision of the problem. NGOs perceive lack of openness from the government to their critique of economic and political interests.

It is not a common practise to re-assess the goals. Opportunities for this are not really there, and goals are set by the central offices. In the case of water sanitation, the government considers the reports that show different advances related to the WTPs, such as the number of plants built, rehabilitated and operating, to be an assessment. The 2014-2018 National Water Plan is the first that includes a biannual policy assessment [53] (p. 57).

The goals and standards of the discharges established by the River Classification are still far from being achieved compared with the current situation, although the governmental levels report some improvements. Now the federal government is concerned because they know that the standards they set are not going to be achieved. The industry sector is more inclined to meet the requirements, but the main challenge is with the municipalities. One of the interviewees even said "the municipalities do not do anything". Only $20 \%$ of the municipalities in the state have discharge permits. The co-investment programs have allowed the WUs to create sanitation infrastructure. The government recognises that problems such as the inoperability of the WTPs due to inadequate technology, legal problems or lack of capacity from the municipalities are still present.

5.4. Strategies \& Instruments-New Instruments at the State Level and the Strategy of Regionalisation Have Supported the Policy Implementation. However, Important Reforms Are Still Required

The main documents establishing water policy with a long-term vision, including sanitation, were the 2030 Water Agenda created in 2011 and now the 2014-2018 National Water Plan. The most important legislative framework for water sanitation consists of: chapter three of the General Law on Environmental Protection, the National Water Law, the State Water Law, the River Classification and the norms. The River Classification is the latest legal instrument that sets water quality discharge limits, goals, and stages for the Atoyac river [51]. NOM-001-SEMARNAT-1996 (establishes the pollution levels for wastewater discharges in national waters), NOM-002-SEMARNAT-1996 (establishes the pollution levels for wastewater discharges in municipal infrastructure) and NOM-003-SEMARNAT-1997 (establishes the pollution levels for treated water and its reuse for public services). Currently, some state reforms to automatically discount the costs of the water treatment plants operation have been applied. This is the case with the Federal Fund for strengthening the municipalities (FORTAMUN), as published in the Official State Gazette on 31 January 2014 and the 2009 reform of article 523 of the Financial Code for the State of Tlaxcala and its Municipalities.

The main programs come from CONAGUA's implementation of the National Water Plan. The master document at the state level is the 2011-2016 State Development Plan. It enables the CEAT with economic resources to create the Program for the State Water Infrastructure [54] (p. 2). Different state actors interviewed referred to the commitment from the governor and the importance of the topic in the state plan. Currently, the state and federal government monitor the industrial sector. However, state level monitoring has no legal consequences.

A new diagnosis of the regionalisation policy is being developed. This study is between the state and federal levels. The monitoring network and improved laboratories are also being built. One of the WUs that is not in charge of WTPs has decided to support the policy with education campaigns in schools to make people aware of the pollution problems. However, the WU mentioned that more 
efforts are required to make people aware of the importance of water service payment, because "society is not used to paying for water".

Among the non-implemented actions is the Atoyac-Zahuapan Commission. The industry sector says that educational programs, technical support or even co-investment policies are missing. Officials at the state level consider that real time monitoring in the river could help them to have more accurate information on the water quality and to find the sources of pollution easier.

Since people have complained that the WTPs are not operating, the government is inviting schools to visit the plants. The state government also keeps its website updated with information about state government actions in favour of water treatment.

The system is based on incentives and it is supposed to create synergy, therefore co-investment for projects is an essential part of the programs. The programs establish clear limits to participation, reducing it in most cases to those with economic contributions. Different actors comment that politicisation and lack of will from various levels of government complicate correct implementation, especially by the municipalities, in part because the state government is an intermediary between the municipalities and the federal programs. Politicisation of the WUs contributes to the lack of enforcement of payments. WUs try to avoid political costs from obliging the citizens to pay. There are no incentives to promote the joint participation between the government and the NGOs. The CORESE meetings do not facilitate this social participation. The government and NGOs do not work together, diminishing the possibilities of synergy created by their cooperation, and the programs working separately lack integral vision.

There are no opportunities to combine or make use of the different types of instruments. Permits can only be adapted to new regulations after five years. Each instrument has its own rules and works separately. The only opportunity to bring the strategies of different stakeholders together is the Atoyac-Zahuapan Commission. It might help to improve coordination, bring efforts together, and provide an integral vision. At the moment, cooperation is the result of obeying the upper levels.

Considering the current practice, important behavioural changes are still required, including stronger enforcement. "For example, wastewater discharge-related sanctions established by the 1981 Federal Duties Law are rarely enforced, and inspections to ensure their compliance are conducted infrequently [... ]" [1] (p. 57).

No measures have been taken to enforce WTPs operation by the WUs. Very few municipalities have discharge permits or operate their WTPs and the federal government finds enforcement complicated. One interviewee said "when an industry is not meeting the norm we can go and seal the company to oblige them, but in the case of the municipalities we cannot do that, reforms need to take place so we can have a way to really force the municipalities to comply with the norm". Enforcement by municipalities in the industry sector is also lacking. NGOs report lack of enforcement in the textile sector and the Industrial Park Quetzalcoatl is among the most criticised.

The industry sector experiences mostly "uneven enforcement". They commented on a case where one company was closed down and apparently due to political contacts it was opened immediately, and also noted that municipalities were not being punished. However, they recognise that there is more pressure from current state and federal administration.

There are also gaps in the current legislation. As mentioned before, the most important is the lack of secondary legislation of the National Water Law, making it difficult to implement [1] (p. 41). The national norms as well as the River Classification need to be updated. NGOs have claimed that there is no regulation on the impact of the mix of various wastes from different industries. They have demanded the creation of a law that stipulates norms depending on the kind of industry and they insist on an integral policy. The Latin American Tribunal of Water notes the lack of law enforcement from all three levels of government.

Currently, the state-owned water quality laboratory monitors the nine water treatments plants operated by the state government as well as 60 municipal water treatment plants. However, the laboratory is not certified, so its results do not have any legal authority. There is still lack of interest 
from the municipalities. The state government complains that they rehabilitate the water treatment plants and the municipalities do not operate them, and they do not have the capacity to sanction them. They are now signing agreements with municipalities to oblige them to operate the plants. According to the CSITARET, all the WTPs employ biological processes, such as: activated sludge, aerated lagoon, anaerobic digester, facultative lagoon, percolator filter, Imhoff tank or artificial wetlands.

\subsection{Responsibilities E Resources—Responsibilities Are Clearly Assigned, However a Considerable Amount of} Economic Resources Is Still Required for Almost All the Phases of Policy Implementation

According to the interviewed actors, responsibilities are clearly assigned by the law. However, important differences are found when it comes to economic resources. While the federal and the state government seem to have resources to continue implementing the water sanitation policy, the municipal government is struggling. For this reason, co-investment in water sanitation programs has been implemented. One study showed that Mexico's water utilities income represents 75\% of their expenses [44] (p. 20). In this regard, some of the interviewed WUs mentioned that the income goes to daily payments and there are no resources left to invest.

The state government has been able to provide economic support to the municipal level; however, more resources are required. The policy of regionalisation has helped to improve this situation, but more resources are needed for rehabilitation programs, to build more laboratories and to maintain the monitoring network. In contrast, the implementation of the Zahuapan Commission has not been facilitated with resources. Cases of corruption have also been found in the application of the programs. A report by the Superior Auditor of Mexico found that there are "limitations in CONAGUA's capacity to document how states manage their resources. It also signalled irregularities in the use of federal programmes' funds such as [ ... ] APAZU" [1] (p. 161).

The three government levels require more staff to monitor the different levels and the industry sector. The government levels that operate WTPs also require more staff for the operation of them.

With the reforms at the state level, more resources for water treatment plants operation have been secured. Also since some plants fulfil the norm, they are receiving economic support from the federal level for their operation. At the same time, money is being invested in the rehabilitation of water treatment plants, as in the case of the plants in Apizaco and Tlaxcala city.

Lack of cooperation is more common at the same government level, than across different levels. At the state level, lack of coordination between Water, Infrastructure and Rural Development was mentioned, however the situation has been improving. The respondents describe the relationship among the Ministries of Finance, Infrastructure, and Water (CEAT) as close. For example, the Ministry of Finance retains the money of the municipalities and make it available for the CEAT, so they can finance the plants operation. Within each government entity a high degree of communication was reported.

One of the most important incoherencies related to the resources is that water tariffs are not established by the WUs according to their necessities, but by the State Congress [44] (p. 21). This leads to politicisation of the costs. Complains about the lack of fulfilment of the municipal responsibilities was common. CONAGUA civil servants commented that only 12 out of 60 are working on their water discharges.

Resources cannot be pooled outside CONAGUA or state programs and they are only available to government actors. The industry and the NGOs work on their own and there is no collaboration among them. Actually, the industry sector perceives NGOs as only criticising without an interest in collaboration.

There is no flexibility in the application of the resources and programs created by the federal government. It is expected that they will be implemented as programmed without changes. Once the program is approved, there is no possibility to make changes until the following year. The state government only has one year to plan and execute programs, so bad planning and poor execution is 
common. Some projects require 6-8 months to be planned and if so, the government only has the next few months to implement them.

The inflexibility in the programs has caused implementation problems and has not contributed to promote accountability. Institutional arrangements also limit accountability. For example, according to the Federal Audit Law, if the Superior Auditor of Mexico finds corruption in a state tender process, he cannot act immediately: the revision process is annual and the Auditor can act just after its completion. Then, he can demand actions from the State Comptroller, appointed by the state governor and therefore part of the same government cabinet. As a result, it is very unlikely that the Comptroller will apply sanctions to the same state government. In March 2013, the Comptroller started an administrative process against state government employees related with PROTAR for the mismanagement of four million USD in 2012 [55]. However, no important actions have been undertaken to address this situation.

Even when there are economic resources, they have not been sufficient to achieve the intended change. Nevertheless, the state government reports progress and the state and federal government feel that there has been sufficient support. Lately, the co-investment budget presented by the federation has been matched by the state government for the water treatment plants construction. CONAGUA "is the biggest spender in the water sector" [1] (p. 27).

In 2013, with the continuous operation of the nine WTPs, $42 \%$ of total discharges in the state are treated meeting the norm NOM-001-SEMARNAT-1996 [54] (p. 9). To achieve this percentage 1.5 million USD were required by the state government, the CONAGUA, the industry sector and the 14 municipalities. Eighty five percent of the total resources was self-generated [54] (p. 10). Monitoring is one of the main challenges, but some efforts are being made. For example, to monitor the accomplishment of the norm NOM-001-SEMARNAT-1996, the state government did 1700 laboratory analyses last year [54] (p. 11). However, there are not enough resources for the inspections to make the industry comply with the norm. When the federal government has tried to enforce the law, it has reported that some industries play around the rules. For example, in some cases textile companies ask their employees to take fabric to their home to be tinted there and the employees accept because they are afraid they will be fired. This makes monitoring more complicated. WUs lack resources to operate the water treatment plants and to monitor the industry sector.

\section{Summary of Findings}

After a systematic analysis of each governance dimension and quality, we assess extent and flexibility as restrictive and coherence and intensity as moderate supportive. In general terms, these qualities create a context that still poses important restrictions, although improvements have been made with the recent reforms at the state level. In the section below we explain this situation in more detail.

Extent was assessed as low, thus restrictive. Extent has been reduced by the regionalisation policy. The state government participates more actively now in the policy implementation through the plants operation and monitoring. There is also a more balanced relationship among the two governmental actors. But the policy is highly governmental-actor centric, there is no social or industry participation and municipal involvement is partial. Various stakeholders' perspectives are not considered. There is a lack of important instruments such as secondary legislation. While both the state reforms and programs have improved the implementation, there is an important lack of resources for monitoring.

Coherence was assessed as moderate, therefore supportive. There is moderate coherence among both relationships: the state and federal level, and the state and municipal government. The regionalisation policy is increasing the coherence between the state and the federal level. The CORESE has had a positive impact, although the Atoyac-Zahuapan Commission has never functioned. There is trust among governmental actors, but they are not trusted by the society. By decreasing the participation of the municipality through the regionalisation policy, the coherence among the state 
and federal actors' perspectives has increased. However, social actors' perspectives are not considered. Coherence of instruments has also increased with the federal and state reforms, although they still work separately. Now that the state has played a more active role in providing more legal and economic resources, coherence with tasks has increased in this regard. However, municipalities are still facing important challenges in operating WTPs.

Flexibility was assessed as low, thus restrictive. There is no degree of adaptation, the rules must be followed as established. The government actors' network is not inclusive and does not create social capital. It is not possible to recombine goals during implementation; until a new administration starts. It is not possible to combine different instruments, each one has its own rules that must be followed. Pooling resources is only possible through the programs' Rules of Operation, and there is no flexibility to do it outside established programs.

Intensity was assessed as low to moderate supportive (improving). Intensity towards the policy implementation is driven by the federal and state government. The industry sector and NGOs do not work together. Goals are still far from being achieved. Many changes still need to take place and laws require enforcement. For example, (1) increasing the number of discharge permits for municipalities; (2) allowing the municipalities to establish their own tariffs; (3) if municipalities have to operate the water treatment plants they should participate from the start of the planning process; (4) more resources should be allocated for monitoring. Table 3 below summarises these findings per governance dimension and quality.

Table 3. Assessment results.

\begin{tabular}{|c|c|c|c|c|}
\hline \multirow[b]{2}{*}{ Governance Dimension } & \multicolumn{4}{|c|}{ Qualities of the Governance Regime } \\
\hline & Extent & Coherence & Flexibility & Intensity \\
\hline Levels \& Scales & Moderate & Moderate & Low & Moderate \\
\hline Actors \& Networks & Low & Low & Low & Low \\
\hline $\begin{array}{c}\text { Problem Perspectives \& } \\
\text { Goal Ambitions }\end{array}$ & Low & Moderate & Low & Low \\
\hline Strategies \& Instruments & Moderate & Moderate & Low & Moderate \\
\hline $\begin{array}{l}\text { Responsibilities \& } \\
\text { Resources }\end{array}$ & Low & Moderate & Low & Moderate \\
\hline Assessed as & Low/Restrictive & Moderate supportive & Low/Restrictive & Low to Moderate \\
\hline
\end{tabular}

\section{Discussion}

In this paper we asked the following question: how apt have the water treatment policy reforms been for the governance context in Tlaxcala's Alto Atoyac sub-basin?

We found that the reforms to promote a more integrated water management and decentralisation in Tlaxcala have failed to provide sufficient results. Examples of cases where bottom-up processes took place are found in common-pool resources literature. Fewer cases have analysed these in a context-sensitive perspective. When examples of water governance improvement are given by international organisations (OECD, UN, CEPAL, World Bank), they correspond to a normative meaning of water governance with "successful" examples of transition from centralised to decentralised systems. At the end such organisations " [ . . ] are increasingly playing a role in the spread of ideas, programs and institutions around the globe" [56] (p. 11). However, decentralisation processes present many challenges and, as research shows, are not a panacea. Our case study provides an example of a more context-sensitive analysis. As we can see from Tlaxcala's case, state reforms have decreased the participation of the municipal government and the Atoyac-Zahuapan Commission has never had a session. This sounds negative, but in this hierarchical context with low capacity at the municipal 
level, these changes have actually increased coherence in the implementation and have allowed a more balanced relationship among the governmental actors.

State and federal governments have the main economic resources and are more stable since they stay in office for six years. Some Mexican states have already decided to manage water at the state level instead of strengthening the decentralisation process, for example in Baja California, Nuevo León, Tabasco, Oaxaca, and Querétaro [44] (p. 17). While only few water utilities among hundreds operate at the state level, five of them are in the top-ten performance [44] (p. 33). However, low stakeholder participation limits the ability to increase resources and makes policies less effective [57] (p. 162). Limited participation lacks the stock of social capital "that is created when a group or organisation develops the ability to work together for mutual productive gain" [58] (p. 302). If more instruments and actors are included, the discretionary decisions can be decreased [59,60]. The Zahuapan River Basin Commission was created, but never enforced. River basin and integrated water resources management are seen as the natural approach for water management [61] (p. 12). However, they have been difficult to implement even in countries that promote them [62] (p. 2). There is an important gap between promise and practice [62] (p. 1). River basin institutions have not been a magic bullet [62] (p. 13). For example, due to the institutional arrangement the Presa Guadalupe Basin Commission in the Estado de Mexico "can only encourage others to take measures and their own capacity to act is very limited" [63] (p. 197). The decentralisation policy strengthens the state level capacities. However, the municipal level is still highly dependent on the upper levels, in economic and politic terms, despite the decentralisation efforts [64]. Federal resources are "the main sources of financing for public water investments" [65]. There has been no improvement in the outcomes of the WUs since the decentralisation process started in the 1980s [66]; in the end, the water treatment plant policy has been implemented through the CONAGUA's programs in a multi-level fashion. Monitoring is still one of the most important challenges at all governmental levels and this creates a serious threat for implementation since "regulations and agreements that cannot be enforced will suffer from a lack of credibility and, in the end, legitimacy" [15] (p. 737).

\section{Conclusions}

We can conclude that the reforms toward decentralisation and integrated water management were less apt for the Tlaxcala sub-basin than the contextual reforms implemented by the state government. This is because the municipality lacks the capacity for policy implementation and because the hierarchical context as well as the institutional arrangement complicates integrated water management implementation. To answer the research question, we applied the Governance Assessment Tool, and the results were as follows: extent and flexibility were assessed as restrictive, while coherence and intensity were found to be moderate supportive for WTP policy implementation. Based on previous research about the qualities of the governance context, we can determine that implementation in the Tlaxcala context is "[ ... ] very strict as it tries to force change through pre-dictating the processes that are followed to achieve the desired results of the upper governmental levels" [24] (p. 57). This situation is supported by the lack of flexibility in the hierarchical context. Therefore, in this context decreasing extent through the regionalisation policy, supports coherence. Increasing coherence has been supported by the most recent reforms at the state level. In this hierarchical context, it actually helps that decisions are taken by a limited number of actors, an outcome that is counter-intuitive when dealing with decentralisation efforts.

The state and federal actors are more stable and have more resources. Municipalities are not equipped and decentralisation reforms of decision making have not had the intended results. The municipalities are highly dependent on the upper levels for resources. In this particular context, state government actors are willing to be involved, but lack legal obligations, so long-term implementation depends on state policy-makers' will. Nonetheless, it delivers better results than leaving the responsibility to the municipalities with their low priority and skills for operating the WTPs. The dependence on the state level creates a challenge, because this level does not have the main 
legal responsibility and new administrations take over every six years, often with contrasting policy priorities. Without the willingness of the state level, the upper level expectations are more prone to be dashed.

The contextual limitations of social actors' participation decreases trust, accountability and long-term implementation. For example, none of the water utility directors knew about the 2030 Water Agenda. In order to improve this situation, higher levels of transparency are still required. Therefore, legal reforms that give the state level more responsibilities and capacities and strengthen transparency, might be a step towards a more effective implementation.

Acknowledgments: We express our gratitude to CONACYT and CONCYTEP for funding this research and to Larry O'Toole, Claudia Pahl-Wostl and the anonymous reviewers from the journal, whose helpful comments improved the quality of this paper.

Author Contributions: The first author conducted this research during his doctoral program under the supervision of the third author. The second author supervised the writing of this article and also reviewed it.

Conflicts of Interest: The authors declare no conflict of interest.

\section{Abbreviations}

The following abbreviations are used in this manuscript:

$\begin{array}{ll}\text { APAZU } & \text { the Urban Potable Water and Sewerage Program } \\ \text { CAPAET } & \text { the State Drinking Water and Sewage Commission } \\ \text { CEAT } & \text { the State Water Commission } \\ \text { CEPAL } & \text { Economic Commission for Latin America and the Carribean } \\ \text { CGE } & \text { the Coordination of Ecology } \\ \text { CIT } & \text { Contextual Interaction Theory } \\ \text { CONAGUA } & \text { National Commission of Water } \\ \text { CORESE } & \text { Commission of Regulation and Follow up } \\ \text { COTAS } & \text { Technical groundwater committees } \\ \text { CSITARET } & \text { the Centre for Integral Water Treatment } \\ \text { ECCAET } & \text { the Company for Control of Polluted Water in the State of Tlaxcala } \\ \text { FORTAMUN } & \text { Federal Fund for Strengthening the municipalities } \\ \text { GAT } & \text { Governance Assessment Tool } \\ \text { IPN } & \text { National Polytechnic Institute } \\ \text { NGO } & \text { Non-governmental organization } \\ \text { OECD } & \text { Organisation for Economic Co-operation and Development } \\ \text { PROSSAPYS } & \text { the Rural Waterworks Development Program } \\ \text { PROTAR } & \text { the Wastewater Treatment Program } \\ \text { UN } & \text { United Nations } \\ \text { WTP } & \text { Water Treatment Plant } \\ \text { WTPs } & \text { Water Treatment Plants } \\ \text { WU } & \text { Water utility } \\ \text { WUs } & \text { water utilities }\end{array}$

\section{References}

1. The Organisation for Economic Co-Operation and Development (OECD). Making Water Reform Happen in Mexico; OECD Publishing: Paris, France, 2013. Available online: http://dx.doi.org/10.1787/9789264187894-en (accessed on 1 December 2015).

2. Pacheco-Vega, R. Arreglos institucionales para el saneamiento de aguas residuales en México. Un caso de estudio en la cuenca Lerma-Chapala. In Gestión del Agua: Una Visión Comparativa entre México y Brasil; Osorio, I.S., do Carmo, R.L., Velázquez, S.V., Guzmán, N.B., Eds.; Instituto Mexicano de Tecnología del Agua (IMTA): Jiutepec, Mexico, 2009; pp. 97-106.

3. UN-WATER. Wastewater Management, A UN-WATER Analytical Brief. UN-WATER. 2014. Available online: http://www.unwater.org/fileadmin/user_upload/unwater_new/docs/UN-Water_Analytical_ Brief_Wastewater_Management.pdf (accessed on 26 March 2016). 
4. Corcoran, E.; Nellemann, C.; Baker, E.; Bos, R.; Osborn, D.; Savelli, H. Sick Water? The Central Role of Waste-Water Management in Sustainable Development. A Rapid Response Assessment; United Nations Environment Programme; UN-HABITAT, GRID-Arendal: Arendal, Norway, 2010. Available online: http://www.unep.org/pdf/SickWater_screen.pdf (accessed on 5 April 2016).

5. Damián, F. PVEM pide sancionar a quien contaminó el río Atoyac (Green party asks sanctions for the Atoyac river polluters). Milenio. 20 March 2016. Available online: http://www.milenio.com/politica/Atoyac_ contaminacion_PVME_atoyac-rio_atoyac_contaminacion_partido_verde_0_704329723.html (accessed on 22 March 2016).

6. Servicios Informativos y Publicitarios del Sureste. Contaminación en el río Atoyac causa enfermedades graves (Pollution in the Atoyac river provokes serious deseases). Milenio. 20 March 2016. Available online: http:/ / sipse.com/mexico/contaminacion-en-el-rio-atoyac-causa-enfermedades-196718.html (accessed on 22 March 2016).

7. Havekes, H.; Hofstra, M.; van der Kerk, A.; Teeuwen, B. Building with Blocks for Good Water Governance; Water Governance Centre: The Hague, The Netherlands, 2013; Available online: http:// watergovernance.s3.amazonaws.com/files/WGC_building_blocks_for_good_governance_def.pdf (accessed on 1 December 2015).

8. Ostrom, E.; Janssen, M.; Anderies, J. Going beyond panaceas. Proc. Natl. Acad. Sci. USA 2007, 104, 15176-15178. [CrossRef] [PubMed]

9. Ansell, C.; Gash, A. Collaborative Governance in Theory and Practice. J. Public Adm. Res. Theory 2007, 18, 543-571. [CrossRef]

10. Pahl-Wostl, C. A conceptual framework for analysing adaptive capacity and multi-level learning processes in resource governance regimes. Glob. Environ. Chang. 2009, 18, 354-365. [CrossRef]

11. Pahl-Wostl, C.; Holtz, G.; Kastens, B.; Knieper, C. Analyzing Complex Water Governance Regimes: The Management and Transition Framework. Environ. Sci. Policy 2010, 13, 571-581. [CrossRef]

12. Pahl-Wostl, C. Water Governance in the Face of Global Change: From Understanding to Transformation; Springer: London, UK, 2015.

13. Thiel, A.; Egerton, C. Re-scaling of Resource Governance as institutional change: The case of water governance in Portugal. J. Environ. Plan. Manag. 2011, 54, 383-402. [CrossRef]

14. Bressers, H.; Kuks, S. Water governance regimes: Dimensions and dynamics. Int. J. Water Gov. 2013, 1, 133-156. [CrossRef]

15. Van Rijswick, M.; Edelenbos, J.; Hellegers, P.; Kok, M.; Kuks, S. Ten building blocks for sustainable water governance: An integrated method to assess the governance of water. Water Int. 2014, 39, 725-742. [CrossRef]

16. Ostrom, E. A General Framework for Analyzing Sustainability of Social-Ecological Systems. Science 2009, 325, 419-422. [CrossRef] [PubMed]

17. Hinkel, J.; Cox, M.E.; Schülter, M.; Binder, C.R.; Falk, T. A Diagnostic Procedure for Applying the Social-Ecological Systems Framework in Diverse Cases. Ecol. Soc. 2015, 20. [CrossRef]

18. Binder, C.; Hinkel, J.; Bots, P.; Pahl-Wostl, C. Comparison of Frameworks for Analyzing Social-Ecological Systems. Ecol. Soc. 2013, 18. [CrossRef]

19. Mollinga, P.; Gondhalekar, D. Finding Structure in Diversity: A Stepwise Small-N Qualitative Comparative Analysis Approach for Water Resources Management Research. Water Altern. 2014, 7, 178-198.

20. Bressers, H.; de Boer, C.; Lordkipanidze, M.; Özerol, G.; Vinke-De Kruijf, J.; Furusho, C.; Lajeunesse, I.; Larrue, C.; Ramos, M.; Kampa, E.; et al. Water Governance Assessment Tool: With an Elaboration for Drought Resilience. 2013. Available online: http:/ /doc.utwente.nl/86879/1/Governance-Assessment-Tool-DROPfinal-for-online.pdf (accessed on 31 July 2014).

21. Bressers, H.; Kuks, S. Integrated Governance and Water Basin Management: Conditions for Regime Change towards Sustainability; Kluwer Academic Publishers: Dordrecht, The Netherlands; Boston, MA, USA; London, UK, 2004.

22. Bressers, H. From public administration to policy networks: Contextual interaction analysis. In Rediscovering Public Law and Public Administration in Comparative Policy Analysis: A Tribute to Peter Knoepfel; Narath, S., Varone, F., Eds.; Presses Polytechniques: Lausanne, Switzerland, 2009; pp. 123-142.

23. De Boer, C.; Bressers, H. Complex and Dynamic Implementation Processes: The Renaturalization of the Dutch Regge River; University of Twente, in Collaboration with the Dutch Water Governance Centre: Enschede, The Netherlands, 2011. 
24. De Boer, C. Contextual Water Management: A Study of Governance and Implementation Processes in Local Stream Restoration Projects. Ph.D. Thesis, Universiteit Twente, Enschede, The Netherlands, 2012.

25. Bressers, H.; Bressers, N. Governance Assessment Guide; DROP Project: Almelo, The Netherlands, 2015; Available online: http:/ / www.dropproject.eu/publications (accessed on 1 December 2015).

26. Gage, R.; Mandell, M. Strategies for Managing Intergovernmental Policies and Networks; Praeger: New York, NY, USA, 1990.

27. Bressers, N.; DROP Partners. Benefit of Governance in Drought Adaptation. A Handbook for Regional Water Authorities; DROP Project: Almelo, The Netherlands, 2015; Available online: http:/ /www.dropproject.eu/ publications (accessed on 1 December 2015).

28. Vinke de Kruijf, J.; Kuks, S.; Augustijn, D. Governance in support of integrated flood risk management? The case of Romania. Environ. Dev. 2015, 16, 104-118. [CrossRef]

29. Casiano, C.; de Boer, C. Symbolic implementation: Governance assessment of the water treatment plant policy in the Puebla's Alto Atoyac sub-basin. Int. J. Water Gov. 2015, 4, 1-22.

30. Jacobson, M.; Meyer, F.; Oia, I.; Reddy, P.; Tropp, H. User's Guide on Assessing Water Governance. 2013. Available online: http://www.undp.org/content/undp/en/home/librarypage/democratic-governance/ oslo_governance_centre/user-s-guide-on-assessing-water-governance/ (accessed on 1 December 2015).

31. The Organisation for Economic Co-operation and Development (OECD). OECD Inventory. Water Governance Indicators and Measurement Frameworks; OECD Publishing: Paris, France, 2015. Available online: http: //www.oecd.org/gov/regional-policy/Inventory_Indicators.pdf (accessed on 1 December 2015).

32. Comisión Nacional del Agua (CONAGUA). Programa Hídrico Regional Visión 2030, Región Hidrológico-Administrativa IV Balsas; Secretaría de Medio Ambiente y Recursos Naturales: México D.F., Mexico, 2012.

33. Instituto Nacional de Estadística y Geografía (INEGI). ConociendoTlaxcala; INEGI: Aguascalientes, Mexico, 2013. Available online: http://www.inegi.org.mx/prod_serv/contenidos/espanol/bvinegi/productos/ estudios/conociendo/TLAXCALA.pdf (accessed on 25 March 2016).

34. Instituto Nacional de Estadística y Geografía (INEGI). Información por Entidad, Tlaxcala; INEGI: Aguascalientes, Mexico, 2010. Available online: http://cuentame.inegi.org.mx/monografias/informacion/ tlax/territorio/div_municipal.aspx?tema=me\&e=29 (accessed on 25 March 2016).

35. Rodríguez, E. Gobernanza del Saneamiento en la Cuenca Atoyac-Zahuapan del Estado de Tlaxcala. Master's Thesis, Instituto Mexicano de Tecnología del Agua (IMTA), Jiutepec, Mexico, 2010. Available online: http:// www.imta.edu.mx/images/pdf/tesis_eva\%20rodriguez\%20rodriguez_2.pdf (accessed on 1 December 2015).

36. Alvarado, M.; Martínez, M.; Rodríguez, R. Evaluación y Monitoreo Ambiental "Cuenca del Río Zahuapan, Estado de Tlaxcala"; SEMARNAT: México D.F., Mexico, 2011. Available online: http:/ /www.inecc.gob.mx/ descargas/cuencas/2011_cnch2_mon_malvarado.pdf (accessed on 26 March 2016).

37. UNAM-Red del Agua and Instituto de Ingeniería. Programa de Apoyo al Desarrollo Hidráulico de los Estados de Puebla, Oaxaca y Tlaxcala. Coordinación Técnica de la Red del Agua UNAM. 2012. Available online: http://www.agua.unam.mx/padhpot/assets/cdh/generales/Reportefinal_formulacion_200812.pdf (accessed on 1 December 2015).

38. Noria, D. Guía para Legisladores en Recursos Hídricos; Fondo para la Comunicación y la Educación Ambiental, A.C.: Mexico D.F., Mexico, 2012. Available online: http://www.agua.org.mx/h2o/index.php? option=com_content\&view=article\&id=24529: guia-para-legisladores-en-recursos-hidricos\&catid=1185: documentos\&Itemid=100117 (accessed on 1 December 2015).

39. Comisión Nacional del Agua (CONAGUA). Política Pública de Mejoramiento de Eficiencias en los Sistemas Urbanos de Agua Potable y Saneamiento en Mexico; SEMARNAT: México D.F., Mexico, 2012.

40. Secretaría de Hacienda y Crédito Público. Presupuesto de egresos de la federación 2016 programas y proyectos de inversion. 2016. Available online: http://pef.hacienda.gob.mx/work/models/PEF/2016/ docs/16/r16_pir.pdf (accessed on 25 March 2016).

41. Comisión Nacional del Agua (CONAGUA). Avance en metas relevantes. 2015. Available online: http:/ /www.conagua.gob.mx/CONAGUA07/Contenido/Documentos/Metas_Relevantes.pdf (accessed on 26 March 2016). 
42. Rodríguez, E. Agua y saneamiento en México: Avances, errores y alternativas. In Agua Potable en Mexico; Olivares, R., Sandoval, R., Eds.; Asociación Nacional de Empresas de Agua y Sanamiento, A.C.: Mexico D.F., Mexico, 2008; pp. 29-47. Available online: http://www.aneas.com.mx/contenido/EL\%20AGUA\% 20POTABLE\%20EN\%20MEXICO.pdf (accessed on 16 August 2013).

43. Jardines, J. La Infraestructura hidráulica Municipal y la participación en su creación y operación de los Gobiernos Federal y Estatal. In Agua Potable en Mexico; Olivares, R., Sandoval, R., Eds.; Asociación Nacional de Empresas de Agua y Sanamiento, A.C.: Mexico D.F., Mexico, 2008; pp. 77-96. Available online: http://www.aneas.com.mx/contenido/EL\%20AGUA\%20POTABLE\%20EN\%20MEXICO.pdf (accessed on 30 August 2013).

44. Instituto Mexicano para la Competividad. Guía para la creación de organismos metropolitanos de agua potable y saneamiento en México. Instituto Mexicano para la Competitividad. 2014. Available online: http:/ /imco.org.mx/wp-content/uploads/2014/03/AguaPotable.pdf (accessed on 1 December 2015).

45. Comisión Nacional del Agua (CONAGUA). Estadísticas del Agua en Mexico, Edición 2013; SEMARNAT: México D.F., Mexico, 2013; Available online: http:/ /www.agua.org.mx/index.php/biblioteca-tematica/ estadisticas/30681-estadisticas-del-agua-en-mexico-edicion-2013 (accessed on 1 December 2015).

46. Mercado, A.; Arellano, S. Senadores exigen rescate del río Atoyac y acciones inmediatas (Senators demand the Atoyac river recovery and inmediate accions). Milenio. 15 March 2016. Available online: http://www.milenio.com/politica/Senadores_Rio_Atoyac-Rio_Atoyac-Rio_Atoyac_sanciones-Rio_ Atoyac_Senado_0_701330102.html (accessed on 25 March 2016).

47. Staff Puebla on Line. El Atoyac, un río muerto por las descargas de 3 mil 500 industrias (The Atoyac, a dead river due to 3500 wastewater discharges from the industry sector). Staff Puebla on Line. 15 March 2016. Available online: http://pueblaonline.com.mx/2015/portal/index.php/estado/item/36617-el-atoyac-unrio-muerto-por-las-descargas-de-3-mil-500-industrias\#.VvWYi2PeLaY (accessed on 25 March 2016).

48. Damián, F.; Zambrano, J. Rio Atoyac: pide el verde sanciones por la contaminación (Atoyac river: The green party requests sanctions for polluters). Milenio. 21 March 2016. Available online: http://www.milenio. com/estados/rio_Atoyac-partido_Verde-sanciones-contaminacion_de_rios_0_704929546.html (accessed on 27 March 2016).

49. Castillo, K.; Viñas, J. Organización demanda nueva ley de agua y servicio municipalizado (NGO demands new water law and municipal water service). E-Consulta.com. 22 March 2016. Available online: http:/ /www.e-consulta.com/nota/2016-03-22/sociedad/organizacion-demanda-nueva-ley-deagua-y-servicio-municipalizado (accessed on 25 March 2016).

50. La Redacción. Inicia CEAT la rehabilitación de 15 plantas tratadoras de aguas residuales (CEAT starts the rehabilitation of 15 water treatment plants). La Jornada de Oriente. 1 April 2014. Available online: http:/ / www.lajornadadeoriente.com.mx/2014/04/01/inicia-ceat-la-rehabilitacion-de-15-plantastratadoras-de-aguas-residuales/ (accessed on 1 December 2015).

51. Secretaría de Gobernación. Declaratoria de clasificación de los ríos Atoyac y Xochiac o Hueyapan, y sus afluentes. Diario Oficial de la Federación. 6 July 2011. Available online: http:/ /dof.gob.mx/nota_detalle. php?codigo=5199672\&fecha=06/07/2011 (accessed on 1 December 2015).

52. Tribunal Latinoamericano del Agua. Veredictos de la Audiencia Pública Regional, México Tribunal Latinoamericano del Agua. Tribunal Latinoamericano del Agua. 2006. Available online: http://tragua.com/ wp-content/uploads/2012/04/R\%C3\%ADo-Atoyac-final.pdf (accessed on 1 December 2015).

53. Comisión Nacional del Agua (CONAGUA). Programa Nacional Hídrico 2014-2018. Available online: http://www.conagua.gob.mx/conagua07/contenido/documentos/PNH2014-2018.pdf (accessed on 1 December 2015).

54. Comisión Estatal de Agua de Tlaxcala and Centro de Servicios Integrales para el Tratamiento de Aguas Residuales del Estado de Tlaxcala. Informe Annual 2013. Available online: http:/ /platrans.tlaxcala.gob.mx/ sistemas/transparencia/view_docs.php?recno=7287 (accessed on 1 December 2015).

55. Ruiz, M. Andan bailando 53 millones, el gobierno federal ya investiga. (Doubts about 53 millions, the federal government is already investigating). E-Consulta Tlaxcala.com. 12 August 2014. Available online: http://archivo.e-consulta.com/blogs/senoriotlaxcalteca/?p=3955 (accessed on 1 December 2015).

56. Dolowitz, D.; Marsh, D. Learning from Abroad: The Role of Policy Transfer in Contemporary Policy-Making. Governance 2000, 13, 5-23. [CrossRef] 
57. Sandfort, J.; Milward, B. Collaborative Service Provision in the Public Sector. In Handbook of InterOrganizational Relations; Cropper, S., Ebers, M., Huxham, C., Smith, P., Eds.; Oxford University Press: Oxford, UK, 2008; pp. 147-174.

58. Agranoff, R.; McGuire, M. Big questions in public network management research. J. Public Adm. Res. Theory 2001, 11, 295-326. [CrossRef]

59. Bryson, J. What to do when stakeholders matter: Stakeholder identification and analysis techniques. Public Manag. Rev. 2004, 6, 41-53. [CrossRef]

60. Klijn, H.; Skelcher, C. Democracy and Governance Networks: Compatible or Not? Public Adm. 2007, 85, 587-608. [CrossRef]

61. Vinke-de Kruijf, J.; Özerol, G. Water management solutions. On panaceas and policy transfer. In Water Governance, Policy and Knowledge Transfer: International Studies on Contextual Water Management; de Boer, C., Vinke-de Kruijf, J., Ozerol, G., Bressers, H.T.A., Eds.; Earthscan Studies in Water Resource Management; Routledge: Aubingdon, Oxon, UK, 2013; pp. 12-35.

62. Ingram, H. Beyond Universal Remedies for Good Water Governance: A Political and Contextual Approach. 2008. Available online: https://www.researchgate.net/publication/238658113_Beyond_ Universal_Remedies_for_Good_Water_Governance_A_Political_and_Contextual_Approach (accessed on 18 March 2016).

63. Franco-Garcia, M.L.; Hendrawati-Tan, L.; Gutierrez-Diaz, C.; Casiano, C.; Bressers, J.T.A. Institutional innovation of water governance in Mexico: The case of Guadalupe Basin, near Mexico City. In Water Governance, Policy and Knowledge Transfer: International Studies on Contextual Water Management; de Boer, C., Vinke-de Kruijf, J., Ozerol, G., Bressers, H.T.A., Eds.; Earthscan Studies in Water Resource Management; Routledge: Aubingdon, Oxon, UK, 2013; pp. 188-204.

64. Rodríguez, V. Decentralization in Mexico; Westview Press: Boulder, CO, USA, 1997.

65. Wilder, M.; Romero, P. Paradoxes of decentralization: Water reform and social implications in Mexico. World Dev. 2006, 34, 1977-1995. [CrossRef]

66. Comisión Nacional del Agua (CONAGUA). Identificacion de Costos para la Sostenibilidad de los Organismos Operadores de Agua. 2015. Available online: http://www.agua.org.mx/biblioteca-tematica/ gestion-del-agua/1258-transparencia-y-rendicion-de-cuentas/37007-identificacion-de-costos-para-lasostenibilidad-de-los-organismos-operadores-de-agua (accessed on 20 March 2016).

(C) 2016 by the authors; licensee MDPI, Basel, Switzerland. This article is an open access article distributed under the terms and conditions of the Creative Commons Attribution (CC-BY) license (http://creativecommons.org/licenses/by/4.0/). 